\title{
General Electric's International Patent Management before World War II
}

\author{
The "Proxy Application" Contract and \\ the Organizational Capability of Tokyo Electric
}

\author{
Shigehiro Nishimura \\ Kyoto University
}

7 he aim of this study is to provide a Japanese case study relating to the international patent management of General Electric

Company (hereafter, GE) prior to World War II, and to show that GE's patent management method brought about a remarkable improvement in the patent management capability of a Japanese enterprise.

Japanese scholars have already pointed out that, before the war, GE had concluded patent agreements with the principal overseas enterprises and that, as the foundation for those agreements, it was submitting patent applications to countries around the globe. ${ }^{1}$ There also exist studies

1. Hiroshi Itagaki, "192onendai Amerika no kaigai tōshi” [U.S. overseas investment in the 1920s], Kokumin keizai no. 136 (1977); Tetsuo Abo, Senkanki Amerika no kaigai tōshi [U.S. overseas investment between the wars] (Tokyo: University of Tokyo Press, 1977); Masaki Yoshida, "188onendai kara 1920nendai ni okeru Amerika denki sangyō no kaigai shinshutsu" [Overseas inroads of the U.S. electrical industry from the 1880 os to the 1920s], Mita shōgaku kenkyū [Mita Business Review] 30 no. 2 (June 1987); Masaki Yoshida, "Amerika oyobi Doitsu denki sangyō ni okeru karuteru keisei to sono kokusaika ni tsuite: senzen no GE o chūshin ni mita tokkyo shihai to karuteru ni yoru 
that have looked at the phenomenon of international patent applications itself and have pointed out that such applications are closely linked with technological domination by multinational corporations. ${ }^{2}$ Nevertheless, almost no light has been shed in previous studies on patent management, which is a business management function that a company carries out. If a patent is merely applied for and registered, that in itself produces no profits for a company at all; on the contrary, it imposes a cost burden on the owner in the form of application costs, an annual fee, and the like. In order for the company to take advantage of the patent system and make a profit, the company has to engage in patent management, an exercise that embraces such things as application, safekeeping, seeking redress for patent infringements and guarding against infringements, patent agreements, and licensing agreements. Since, in industrial nations where patent systems are in place, there is regulation of the production and sale of goods that involve the use of technology that a patent owner is holding the rights over, any analysis of a company's business history must shed light not only on production management or the management of distribution and sales, but also on patent management. Furthermore, when a company's activities spread to overseas countries, patent management also takes place in those countries into which the company moves. Thus when somebody sets out to shed light on the methods and organization by which a company becomes international in its activities, it is considered necessary to shed an equal level of light on the methods and organization of that company's patent management as on its management of local production, distribution, and the like. The company that this present study analyzes is a technology-intensive corporation; it not only has acquired and manages a large number of patents in the United States, but it also is a classical example of a corporation that has made inroads into overseas countries through the acquisition of a large number of patent rights in overseas countries. In this paper I set myself two tasks, therefore, the aim of which is to shed light on the methods and organization of GE's patent management in Japan.

shijō tōsei" [The formation of cartels in the U.S. and German electrical industries and their internationalization: Patent domination and market control by cartels as seen by focusing on prewar GE], Mita shōgaku kenkyū 30 no. 4 (October 1987).

2. See Takabumi Hayashi, Takokuseki kigyō to chiteki shoyūken: tokkyo to gijutsu shihai no keizaigaku [Multinational corporations and intellectual property rights: The economics of patents and technology control] (Tokyo: Moriyama Shoten, 1989). 
The first task is that of comparing the method of international patent management between the wars with the way international patents were managed before World War I, and doing so from the perspective of international comparisons. The patent agreement entered into between GE and Tokyo Electric Co., Ltd. (hereafter, Tokyo Electric) in 1905 was supplanted by an agreement between the latter and International General Electric Company, a subsidiary of GE; included in this later agreement was an international patent management agreement known as a "proxy application" contract. This contract has passed almost unnoticed in the literature. John Cantwel and Tetsuo Tomita have drawn attention to its existence. Cantwel, making a survey of the Official Gazette of the United States Patent and Trademark Office, has pointed out that the nationalities of inventors named in patents acquired in the United States by GE are spread across a large number of countries outside the United States, and he has argued for the existence of international R \& D activities by multinational corporations in the 1930s. ${ }^{3}$ Tomita's research involved a study of the Japanese situation through a similar survey of Japan Patent Office materials. ${ }^{4} \mathrm{He}$ discovered that there are a large number of patents, among Japanese patents acquired by Tokyo Electric and other Japanese enterprises, whose inventors are non-Japanese. He points out that this phenomenon shows that patent rights were transferred between cartel companies, and he proves that technological transfers were carried out via these cartels. Unfortunately, neither Cantwel nor Tomita tell us in their works why (i.e., for what purposes) patent rights were transferred, nor the effects that such transfers had on the management of the companies involved.

My second task is to provide a clear picture of the transfer of patent management functions from GE to Tokyo Electric. Professor Shin Hasegawa has shown that Tokyo Electric's business expansion in the 1920 s was mainly due to an improvement in its organizational capability for technological development. Now, though he has shed light on

3. John Cantwel, "The Globalization of Technology: What Remains of the Product Cycle Model?", Cambridge Journal of Economics 19 (1995), pp. 155-74.

4. Japan Patent Office, Kögyõ shoyūken seido hyakunen shi [One hundred years of the industry property rights system], vol. 1 (Tokyo: The Japan Institute of Invention and Innovation, 1984), pp. 662-68; Tetsuo Tomita, Shijō kyōsō kara mita chiteki shoyūken [Intellectual property rights seen from the perspective of market competition] (Tokyo: Daiyamondo Sha, 1993), pp. 101-110. 
the expansion of the company's research and development structure, ${ }^{5}$ I believe that improvement in patent management capability must be included within organizational capability for technological development. This is because, by establishing a patent department, an enterprise is able to acquire not only the function of gaining rights over the technology it has developed but also the function of encouraging technological development. In this present study I interpret the setting up and firm establishment of a patent department in Tokyo Electric in 1921 to be a transfer of patent management functions that follows from the "proxy application" contract (= international patent management agreement), and I clarify what GE's international patent management organization was in the period between the two world wars.

My presentation will proceed in the following sequence. Under the next major heading I shall discuss GE's patent management methods and organization before World War I as seen through an analysis of its management of the tungsten light bulb patent, and in particular the tungsten light bulb patent trials that were a concrete manifestation of that management. Under the second major heading I shall explain the contents of the "proxy application" contract and highlight the special features of GE's international patent management during the period between the two wars; at the same time I shall elucidate how that contract provided Tokyo Electric with the incentive to set up a patent department and how patent management functions were transferred from GE to Tokyo Electric.

\section{PATENT MANAGEMENT PRIOR TO WORLD WAR I}

\section{The Management of the Tungsten Patent in Japan}

In Japan there did not exist a powerful basic patent for tungsten filaments such as the Just-Hanaman patent in the United States; instead,

5. See Shin Hasegawa, "Gijutsu dōnyū kara kaihatsu e" [From the introduction of technology to development], in Daikigyō jidai no tōrai [The arrival of the age of large corporations], ed. Tsunehiko Yui and Eisuke Daitō (Tokyo: Iwanami Shoten, 1985) and, by the same author, "Gaishi-kei kigyō no keiei hatten to soshiki nōryoku: Tōkyō Denki no jirei bunseki" [The business expansion and organizational capability of foreignaffiliated companies: Analyzing the case of Tokyo Electric], Aoyama keiei ronshū [Aoyama Journal of Business] 30 no. 3 (November 1995). 
for some time a number of alternative tungsten patents existed side by side. Though GE had acquired a Japanese patent for tungsten light bulbs developed by itself, leading tungsten light bulb patents were also held in Japan by German companies such as AEG (Allgemeine ElektricitätsGesellschaft) and Auergesellschaft (Deutsche Gasglüchlicht AktienGesellschaft). Using as a bargaining tool the patent for the drawn-wire tungsten filament developed by the physicist William D. Coolidge, GE negotiated an international agreement that placed the above-mentioned Japanese patents owned by German companies under GE's management. $^{6}$

Relations between GE and German companies in Japan go back to 1903, when GE and AEG concluded an international agreement. In this 1903 agreement, Japan was included in "the rest of the world," and both companies were permitted to engage in business there. ${ }^{7}$ For a while both GE and AEG were able to export light bulbs to Japan and produce them in Japan, and both companies pushed ahead with light bulb operations in the country. In 1910, however, the two companies held negotiations over the Japanese market. In May 1910 GE forwarded through its agent, Seiichi Kishi, a letter to the Ōkuragumi (AEG's agent in Japan) advising them that AEG's imported light bulbs were infringing GE's Japanese patents. ${ }^{8}$

6. The pressed tungsten filament that existed before Coolidge's invention was far more efficient than the carbon light bulb, but at the same time it was extremely fragile and easily breakable. During his research on metals and metallurgy, Coolidge discovered that the keys to giving tungsten pliability and ductility were mechanical working and temperature control. In 1910 he succeeded in giving tungsten malleability and strength by mechanically processing it when it was in a heated state, and he developed a method of drawing a wire from an opening in the heated dies. GE applied for patents on Coolidge's invention all over the world, including in Japan, in that same year, 1910. As a result GE acquired product patent no. 18961 and method patent no. 20894. See A. A. Bright, Jr., The Electric-Lamp Industry: Technological Change and Economic Development from 1800 to 1947 (New York: Macmillan, 1949; reprinted by Arno Press, 1972), pp. 194-96.

7. Shin Hasegawa, "Competition and Cooperation in the Japanese Electrical Machinery Industry," in International Cartels in Business History, ed. Akira Kudō and Terushi Hara (Tokyo: University of Tokyo Press, 1992), pp. 166-67.

8. For more details on the negotiations between GE and AEG, see Shin Hasegawa, "Ōkuragumi no denki kikai bijinesu to AEG no tainichi senryaku: daiichiji taisen izen ni okeru GE no tokkyo senryaku to no kankei de" [Ōkuragumi's electrical machinery business and AEG's strategies vis-à-vis Japan: In connection with GE's patent strategies prior to World War I], Aoyama keiei ronshü 30 no. 1 (July 1995). 
Negotiations between GE and AEG began, and at a meeting in September 1911 it was established that GE had the legal advantage. Because AEG was a member of a cartel organized in Germany, its exports of carbon filament lamps were restricted, and because of the existence of the Coolidge patents it could not freely export to Japan drawn-wire tungsten light bulbs either. ${ }^{9}$ While AEG was allowed to sell metal-filament light bulbs other than drawn-wire tungsten light bulbs, the fact that it did not possess any valid Japanese patents made the exporting and production of light bulbs an unrealistic proposition. Acknowledging the legal advantage of GE in Japan's light bulb market, in January 1914 AEG concluded a sales agreement with Tokyo Electric in regard to light bulbs. ${ }^{10}$

It is believed that German companies other than AEG were not allowed to enter Japan because of a permission to use the Coolidge patents granted them by GE through a filament trust (Drahtkonzern) created in Germany. ${ }^{11}$ It was because AEG already had an agreement with GE regarding sales in Japan prior to the formation of the filament trust that GE had been forced to negotiate with AEG from 1910 in order to establish GE's legal advantage. There was another German company that owned an important patent in Japan, and this was Auergesellschaft, which owned Dr. Fritz Blau's patents. It is believed that Auergesellschaft's Japanese patents also fell under GE's management through the mediation of the Drahtkonzern. Thus it came about that all of the principal light bulb patents owned by German companies in Japan came to be managed by GE.

Once the patents of German companies were under its management, moves by GE to lead the way in reorganizing and concentrating the light bulb industry in Japan soon emerged-as early as 1914. In April $1914 \mathrm{GE}$, along with AEG and Auergesellschaft, sent a warning letter to Tokyo Denkyū Seisakusho. ${ }^{12}$ Over the joint signatures of GE's agent,

9. Ibid., pp. 14-15.

10. Ibid., p. 17.

11. The filament trust was a cartel formed by a union of AEG, Siemens \& Halske A.G., and Auergesellschaft, and it pooled the metal-filament patents held by the three companies. See G. W. Stocking and M. W. Watkins, Cartels in Action: Case Studies in International Business Diplomacy (New York: The Twentieth Century Fund, 1946), pp. 316-17. GE worked through the filament trust to license the Coolidge patents to Siemens \& Halske and Auergesellschaft.

12. Jirō Watanabe, ed., Tangusten tokkyo denkyū mondai [Problems connected with 
Table 1. Patents Listed in Warning Letter

\begin{tabular}{|c|c|c|c|c|}
\hline $\begin{array}{l}\text { Patent } \\
\text { No. }\end{array}$ & $\begin{array}{c}\text { Applica- } \\
\text { tion }\end{array}$ & Registration & Patentee & Title \\
\hline 10148 & $\begin{array}{l}11 \text { Jan. } \\
1906\end{array}$ & $\begin{array}{l}5 \text { March } \\
1906\end{array}$ & $\begin{array}{l}\text { Deutsche Gasglühlicht } \\
\text { Aktien-Gesellschaft (Auer- } \\
\text { gesellschaft) }\end{array}$ & $\begin{array}{l}\text { "Method of making filament } \\
\text { of incandescent lamps" }\end{array}$ \\
\hline 10877 & $\begin{array}{l}11 \text { Jan. } \\
1906\end{array}$ & $\begin{array}{l}17 \text { Aug. } \\
1906\end{array}$ & $\begin{array}{l}\text { Deutsche Gasglühlicht } \\
\text { Aktien-Gesellschaft (Auer- } \\
\text { gesellschaft) }\end{array}$ & $\begin{array}{l}\text { "Incandescent lamps with } \\
\text { metal tungsten filament" }\end{array}$ \\
\hline 18980 & $\begin{array}{l}2 \text { Oct. } \\
1906\end{array}$ & $\begin{array}{l}15 \mathrm{Dec} . \\
1910\end{array}$ & $\begin{array}{l}\text { Deutsche Gasglühlicht } \\
\text { Aktien-Gesellschaft (Auer- } \\
\text { gesellschaft) }\end{array}$ & $\begin{array}{l}\text { "Incandescent lamps with } \\
\text { hanger devices for filament" }\end{array}$ \\
\hline 18961 & $\begin{array}{l}12 \text { Aug. } \\
1910\end{array}$ & $\begin{array}{l}13 \mathrm{Dec} . \\
1911\end{array}$ & General Electric Company & "Tungsten products" \\
\hline 20894 & $\begin{array}{l}12 \text { Jan. } \\
1910\end{array}$ & $\begin{array}{l}30 \text { Oct. } \\
1911\end{array}$ & General Electric Company & $\begin{array}{l}\text { "Method of making kneaded } \\
\text { tungsten for use as filaments } \\
\text { of incandescent electric lamps } \\
\text { and for other purpose" }\end{array}$ \\
\hline 22829 & $\begin{array}{c}13 \text { Oct. } \\
1910\end{array}$ & $\begin{array}{l}90 \mathrm{ct} . \\
1912\end{array}$ & $\begin{array}{l}\text { Allgemeine Elektricitäts- } \\
\text { Gesellschaft }\end{array}$ & $\begin{array}{l}\text { "Method of shaping a metal } \\
\text { incandescent filament" }\end{array}$ \\
\hline
\end{tabular}

Source: Jirō Watanabe, ed., Tangusten tokkyo denkyū mondai [Problems connected with tungsten patent light bulbs] (Yokohama: Jirō Watanabe, 1920), Section 2, pp. 32-34.

Seiichi Kishi, AEG's agent, Washitarō Nagashima, and Auergesellschaft's agent, Dr. Karl Vogt, the warning letter stated that, if Tokyo Denkyū Seisakusho did not stop making light bulbs that infringed patents, the three companies would take legal action. This was followed with a list of the patents that were being infringed (see Table 1). All of these were patents that covered things that were essential for the making of tungsten light bulbs. This joint-signature warning letter shows that, in April 1914, GE already had in place procedures for management of its own and other companies' patents; it also shows that the patents that GE was managing covered all the main parts of tungsten light bulb manufacture, and that GE was in an extremely strong position.

From the above it is clear that, prior to World War I, GE was managing the principal tungsten light bulb patents held in Japan by German

tungsten patent light bulbs] (Yokohama: Jirō Watanabe, 1920), Section 2, pp. 4-5. (This work is in the possession of the Kyoto University Library; the pagination in each section begins from 1.) 
companies. The form that management took was one of direct patent management. Now, GE's first serious entry into Japan's light bulb market had occurred in 1905, when it concluded with Tokyo Electric a contract covering capital participation and a technical tie-up. On the basis of this contract GE supplied Tokyo Electric with machinery and equipment to manufacture light bulbs, and it sent the engineer W. T. McChesney to install the machines and equipment, to oversee operations, and to impart light bulb manufacturing know-how. GE also gave permission for Tokyo Electric personnel to visit GE factories and receive technical training there. From the contents of this contract it is apparent that, at the time of the tie-up, GE was making Tokyo Electric its light bulb production base in Japan and East Asia. Through the presentation of light bulb manufacturing machinery and equipment, the light bulb production processes that had been carried out by hand were for the most part mechanized, so that Tokyo Electric's light bulb production capability improved dramatically. ${ }^{13}$ But when one looks at the patent contract with a critical eye, it is clear that GE did nothing more than give Tokyo Electric an exclusive license to use the patents GE had applied for and gained in Japan. ${ }^{14}$ It can be said that, prior to World War I, there existed a functional division-of-labor relationship in which GE itself was managing the patents that it was licensing to Tokyo Electric, while the latter was involved exclusively with production and sales.

It becomes clear from a scrutiny of GE's international contracts with other foreign companies, however, that this division-of-labor relationship in Japan was a special case. Table 2 offers a comparison of how GE managed Coolidge's drawn-wire tungsten light bulb patents with Japan as compared with what it did in the United States, Great Britain, and Germany. First of all, let it be noted that, in Great Britain, BTH (British

13. Hoshimi Uchida, "Western Big Business and the Adoption of New Technology in Japan: The Electrical Equipment and Chemical Industries 1890-1920," in Development and Diffusion of Technology: Electrical and Chemical Industries, ed. Akio Okochi and Hoshimi Uchida (Tokyo: University of Tokyo Press, 1980), pp. 155-57.

14. See Shōtarō Yasui, ed., Tōkyō Denki Kabushikigaisha gojūnen shi [A fifty-year history of Tokyo Electric Co., Ltd.] (Tokyo: Tokyo-Shibaura Electric Co., Ltd., 1940), pp. 99 and 113-14; and Yoshikatsu Hayashi, "Denki sangyō ni okeru Amerika no gijutsu dōnyū-seiki tenkanki moo hitotsu no Nichi-Bei kankei" [The introduction of American technology in the electrical industry: Another Japan-U.S. relationship at the turn of the century], Sundai shigaku [Sundai Historical Review] no. 61 (March 1984), p. 65. 
Table 2. Coolidge Patents in Several Countries

\begin{tabular}{|c|c|c|c|c|c|}
\hline & Japan & Japan & United States & Great Britain & Germany \\
\hline Patent No. & 18961 & 20894 & 1082933 & 8031 AD 1910 & 269498 \\
\hline \multirow[t]{2}{*}{ Application } & 12 Aug. 1910 & 12 Jan. 1910 & 19 June 1912 & 2 April 1910 & $\begin{array}{c}6 \text { Oct. } 1909 \\
\left(1^{\text {st }} \text { Paragraph }\right.\end{array}$ \\
\hline & $\begin{array}{l}\text { (Japanese General } \\
\text { Government in } \\
\text { Korea) }\end{array}$ & & & $\begin{array}{l}3 \text { Oct. } 1910 \\
\text { (Complete } \\
\text { Specification) }\end{array}$ & $\begin{array}{l}23 \text { Feb. } 1910 \\
\left(2^{\text {nd }} \text { Paragraph) }\right.\end{array}$ \\
\hline \multirow[t]{4}{*}{$\begin{array}{r}\text { Registration/ } \\
\text { Issue }\end{array}$} & 27 Aug. 1910 & 30 Oct. 1911 & 30 Dec. 1913 & 3 July 1911 & 6 Oct. 1910 \\
\hline & $\begin{array}{l}\text { (Japanese General } \\
\text { Government in } \\
\text { Korea) }\end{array}$ & & & & 24 Jan. 1914 \\
\hline & 13 Dec. 1910 & & & & \\
\hline & $\begin{array}{l}\text { (Japan Patent } \\
\text { Office) }\end{array}$ & & & & \\
\hline Inventor & $\begin{array}{l}\text { William D. } \\
\text { Coolidge }\end{array}$ & $\begin{array}{l}\text { William D. } \\
\text { Coolidge }\end{array}$ & $\begin{array}{l}\text { William D. } \\
\text { Coolidge }\end{array}$ & $\mathrm{N} / \mathrm{A}$ & N/A \\
\hline Patentee & GE & GE & GE & BTH & AEG \\
\hline Title & $\begin{array}{l}\text { "Tungsten } \\
\text { products" }\end{array}$ & $\begin{array}{l}\text { "Method } \\
\text { of making } \\
\text { kneaded tung- } \\
\text { sten for use as } \\
\text { filaments of } \\
\text { incandescent } \\
\text { electric lamps } \\
\text { and for other } \\
\text { purpose" }\end{array}$ & $\begin{array}{l}\text { "Tungsten } \\
\text { and method } \\
\text { of making the } \\
\text { same for use } \\
\text { as filaments of } \\
\text { incandescent } \\
\text { electric lamps } \\
\text { and for other } \\
\text { purpose" }\end{array}$ & $\begin{array}{l}\text { "Improve- } \\
\text { ments relat- } \\
\text { ing to tung- } \\
\text { sten and the } \\
\text { manufacture } \\
\text { thereof" }\end{array}$ & $\begin{array}{l}\text { "Verfahren zur } \\
\text { Herstellung } \\
\text { von Wolfram- } \\
\text { frahten für } \\
\text { Glühkorper } \\
\text { elektrischer } \\
\text { Glühlampen" }\end{array}$ \\
\hline $\begin{array}{r}\text { Patent } \\
\text { Attorney }\end{array}$ & Seiichi Kishi & Seiichi Kishi & $\begin{array}{l}\text { Newton A. } \\
\text { Brugress } \\
\text { Heten Orfird }\end{array}$ & John Gray & N/A \\
\hline
\end{tabular}

Source: J. Watanabe, Problems Connected with Tungsten Patent Light Bulbs, Section 3, p. 8 (with some additions and emendations based on patent specifications).

Thomson-Houston Co., Ltd.), which had concluded a patent agreement with GE, made the application for the Coolidge patents and was also the patentee. In Germany the same thing happened, with AEG making the application and also being the patentee. In Japan, however, the Coolidge patents were not registered by Tokyo Electric but, as in the United States, they were registered by GE itself as the patentee. Therefore, whereas in Great Britain and Germany BTH and AEG became the patentees and 
themselves applied for the patents that GE had transferred to them, and when they acquired the patents they handled the management of the GE patents, in Japan all this was carried out through the patent attorney Seiichi Kishi. ${ }^{15}$ Japan's Patent Law stipulates that non-Japanese must nominate a patent attorney who is a resident within the Japanese Empire, so in accordance with this regulation GE carried out direct patent management with Kishi as its patent attorney. GE would handle all its patent applications in Japan through Kishi's law office, and it would also proceed with concentrating Japan's electric light bulb industry through judicious use of patent judgments and patent trials, with Kishi acting as its patent attorney.

\section{Tungsten Light Bulb Lawsuits}

The fact that GE managed almost all of the important light bulb patents in Japan meant that none of the light bulb manufacturers in Japan except Tokyo Electric were able to produce or sell any light bulbs at all unless they capitulated to GE. Faced with this situation, Japan's light bulb manufacturers tried to get around GE's control by using as their weapon those tungsten light bulb patents that GE exercised no control over.

In the wake of the development of hydroelectric power sources after the Russo-Japanese War, electric light bulb companies began mushrooming from the year 1907 onwards. ${ }^{16}$ Those companies that were manufacturing only carbon light bulbs faced hard times when tungsten light bulbs appeared, however, and they also experienced technological difficulties when it came to switching to the manufacture of tungsten light bulbs. As a result of these circumstances, in 1912 Osaka Denkyū

15. Kishi was one of 138 patent attorneys registered at the end of 1899 . He was well known as an agent who specialized in dealing with the patents of non-Japanese. He not only was an advocate of the introduction of foreign capital into Japan, he also actually acted as an intermediary in cases involving the introduction of foreign capital. For example, it was Kishi who acted as intermediary in a tie-up between Murai Brothers \& Co. (Murai Kyōdai Shökai) and American Tobacco. See Benrishi seido 1oonen shi [One hundred years of the patent attorney institution], compiled by Benrishi Kai [Patent Attorney Association] (Tokyo: Benrishi Kai, 200o), pp. 22-23, and Wasaburō Itō, ed., Kishi Seiichi den [The life of Seiichi Kishi] (Tokyo: Kishi Dōmonkai), pp. 361-63.

16. Nihon Denkyũ Kōgyōkai [Japan Electric Light Bulb Manufacturers' Association], comp., Nihon denkyū kōgyō shi [A history of the Japanese light bulb industry] (Tokyo: Nihon Denkyū Kōgyōkai, 1963), pp. 53-56. 
Co., Ltd., concluded a patent agreement regarding the manufacture and sale of tungsten light bulbs with Tokyo Electric, and joined the GE group of affiliated companies; in 1913 Teikoku Denkyū Co., Ltd., and Nihon Denkyū Co., Ltd., followed suit. Finally, in 1914 Tokyo Denkyū Seisakusho, which had received the warning letter mentioned earlier, concluded a patent agreement with Tokyo Electric, and likewise joined the GE group. ${ }^{17}$

Another boom in electric light bulb companies occurred in the mid1910 about the time of the outbreak of World War I. ${ }^{18}$ The companies that were set up at this time, however, did not base their businesses on light bulb patents that they themselves developed, but on patents owned by foreigners other than GE. Dainihon Denkyū Co., Ltd., and Kansai Denkyū Co., Ltd., were both set up in 1915, while Taishō Denkyū Co., Ltd., was set up in Kyūshū in 1916. Dainihon Denkyū was set up in an attempt to industrialize the Japanese patent of the Swiss inventor Godlieb Gmür; Kansai Denkyū aimed at doing the same with the Japanese patent of the British Westinghouse Metal Filament Lamp Co., Ltd.; and Taishō Denkyū was set up to industrialize the patent of Nobumi Okamoto. $^{19}$

The establishment of these three companies threatened to poke a hole in the patent monopoly that GE had carefully constructed in Japan by 1914, and it also represented a formidable challenge that could have an impact on GE's relations with German companies. GE considered their existence dangerous enough to instigate a series of lawsuits against the three companies. Table 3 lists the patents that were at issue between $\mathrm{GE}$ and the three companies in these patent lawsuits. While the patents that the three companies were dependent upon differed in content from the Coolidge patents, the point at issue was that the methods used by the three companies to manufacture the ductile tungsten used in the tungsten light bulb fell within the scope of the Coolidge patent rights. If GE were to allow the industrialization of any patent that was similar to the

17. S. Yasui, A Fifty-Year History of Tokyo Electric Co., Ltd., pp. 135-37.

18. Nihon Denkyũ Kōgyōkai, A History of the Japanese Light Bulb Industry, pp. 67-70.

19. The reading "Nobumi" for Okamoto's personal name is not known for certain, but this is the most likely reading. From what is said in the second paragraph below, it seems that Okamoto's patent was the result of Okamoto's application in Japan for a patent on the invention of an Englishman. 
Table 3. Patents Involved in Tungsten Patent Lawsuits

\begin{tabular}{|c|c|c|c|c|c|c|c|}
\hline Patent No. & Application & Registration & $\begin{array}{c}\text { Patentee } \\
\text { (at Registration) }\end{array}$ & $\begin{array}{l}\text { Patentees } \\
\text { Nationality }\end{array}$ & Inventor & $\begin{array}{l}\text { Inventor's } \\
\text { Nationality }\end{array}$ & Subject \\
\hline 18961 & 12 Aug. 1910 & 13 Dec. 1910 & General Electric Company & US & $\begin{array}{l}\text { William D. } \\
\text { Coolidge }\end{array}$ & US & ductile tungsten \\
\hline 20894 & 12 Jan. 1910 & 30 Oct. 1911 & General Electric Company & US & $\begin{array}{l}\text { William D. } \\
\text { Coolidge }\end{array}$ & US & $\begin{array}{l}\text { method of making ductile } \\
\text { tungsten }\end{array}$ \\
\hline 26704 & 1 April 1914 & 19 Oct. 1914 & $\begin{array}{l}\text { Glühfadenfabrik Aarau A-G } \\
\text { vormals Gmür \& Company }\end{array}$ & Swiss & $\begin{array}{l}\text { Godlieb } \\
\text { Gmür }\end{array}$ & Swiss & $\begin{array}{l}\text { method of making tungsten or } \\
\text { the same ductile }\end{array}$ \\
\hline 24027 & 26 June 1912 & 26 May 1913 & $\begin{array}{l}\text { The British Westinghouse } \\
\text { Metal Filament Lamp Co., } \\
\text { Ltd. }\end{array}$ & UK & $\begin{array}{l}\text { Dr. Anton } \\
\text { Lederer }\end{array}$ & Austrian & $\begin{array}{l}\text { method of making metal or alloy } \\
\text { ductile }\end{array}$ \\
\hline 27165 & 11 Sept. 1912 & 23 Jan. 1915 & $\begin{array}{l}\text { The British Westinghouse } \\
\text { Metal Filament Lamp Co., } \\
\text { Ltd. }\end{array}$ & UK & $\begin{array}{l}\text { Dr. Anton } \\
\text { Lederer }\end{array}$ & Austrian & $\begin{array}{l}\text { supplemental invention to Pat. } \\
\text { No. } 24027\end{array}$ \\
\hline 28846 & 7 Sept. 1915 & 8 Jan. 1916 & Okamoto Nobumi & Japanese & $\begin{array}{l}\text { Okamoto } \\
\text { Nobumi }\end{array}$ & Japanese & $\begin{array}{l}\text { method of making tungsten or } \\
\text { tungsten alloy }\end{array}$ \\
\hline
\end{tabular}

Source: The above data has been compiled from Japan Patent Office, comp., Patent Gazette. 
Coolidge patents, the effectiveness of the group of tungsten patents that GE managed would be weakened, and the expansion of its electric light bulb operations in Japan would be in jeopardy.

J. R. Geary, the person responsible for GE operations in Japan, sent a warning letter to interested parties of Taishō Denkyū on 19 February 1916 , prior to the company's establishment. ${ }^{20}$ In the letter, after Geary explained that GE was managing a group of patents covering processes that were essential to the manufacture of tungsten electric light bulbs, he pointed out that the Okamoto patent (No. 28846) that Taishō Denkyū was about to industrialize was the same in content as that of British Patent No. 16066 AD 1913, invented by a British citizen, Ernst August Krüger, and that this same Krüger had lost the case in a trial involving the Coolidge patents in England. Despite Geary's appeal in the warning letter that the company not be established, in the end its establishment went ahead five days later, on 24 of February. To deal with the situation, on 2 June 1916 GE executed a demand for trial for invalidation of the Okamoto patent against Taishō Denkyū, naming as the demandant Tokyo Denkyū Seisakusho, a member of the GE group. ${ }^{21}$

GE next submitted to the Tokyo District Court on 15 August 1916 a request for an injunction against Dainihon Denkyū for infringements of Coolidge patent No. 18961 and a demand for indemnity. ${ }^{22}$ On 15 January 1917 GE submitted to the Patent Office a demand for trial for confirmation of scope of right regarding the Coolidge patents and a demand for trial for invalidation of the Gmür patent. ${ }^{23}$ Dainihon Denkyū fought back by submitting to the Patent Office on 10 July a demand for trial for invalidation, seeking the invalidation of the Coolidge patents. ${ }^{24}$ GE retaliated by submitting on 9 December 1918 a demand for trial for confirmation of scope of right in regard to Coolidge's method patent (No. 20894); Dainihon Denkyū submitted on 19 March 1919 a counterdemand for trial for invalidation of Coolidge's method patent. ${ }^{25}$

20. J. Watanabe, Problems Connected with Tungsten Patent Light Bulbs, Section 2, pp. 11-15.

21. Ibid., Section 2, pp. 1-3.

22. Ibid., Section 3, pp. 1-4.

23. Ibid., Section 4, pp. 1-12 and Section 8, pp. 1-9.

24. Ibid., Section 7, pp. 1-9.

25. Ibid., Section 10, pp. 1-13 and Section 11, pp. 1-11. 
While proceeding with legal battles against Taishō Denkyū and Dainihon Denkyū, GE instituted a lawsuit against Kansai Denkyū as well. On 19 March 1917 GE submitted to the Patent Office a demand for trial for invalidation of two patents owned by British Westinghouse; ${ }^{26}$ it also filed criminal charges in the Osaka District Court in May of the same year, naming Kansai Denkyū as the corporate body and its directors as defendants. ${ }^{27}$ Kansai Denkyū fought back by submitting to the Patent Office in June of that year a demand for trial for invalidation of the Coolidge patents. ${ }^{28}$

In this series of tungsten patent trials, the common point at issue was the validity of the Coolidge patents, particularly the product patent No. $18961 .^{29}$ In its preparation to proceed with this series of patent trials, GE kept in close contact with the patent attorney Seiichi Kishi. On 17 August 1916, two days after GE submitted its first civil suit against Dainihon Denkyū, Kishi and another member of his law office, Shunkichi Kimura, were on a ship bound for the United States. ${ }^{30}$ In the United States Kishi had direct discussions with GE's legal experts, and they mapped out strategies for the tungsten lawsuits in Japan. Kishi and Kimura also obtained possession of information on the tungsten trials that had taken place in Great Britain and Germany, and they were back in Japan on 16 October 1916. After their return, during the trials Kishi, acting on behalf of GE, maintained that the drawn-wire tungsten invented by Coolidge was something completely new, and he made use of the decisions handed down in Great Britain and Germany to back up his position. Taishō Denkyū, Dainihon Denkyū, and Kansai Denkyū countered by maintaining that the ductility of pure tungsten was an already known fact, and so Patent No. 18961 was invalid. ${ }^{31}$

26. Ibid., Section 9, pp. 1-6 and pp. 21-27.

27. Ibid., Section 6, p. 1.

28. Ibid., Section 6, pp. 2-5.

29. In January 1917 another court case arose when Tatsunosuke Ōshima, president of Ōshima Denki Kōmusho, filed with the Patent Office a demand for trial for invalidation of the Coolidge patents against GE. It was deliberated at the same time as the other patent lawsuits, but on 22 April 1920 the case was dismissed on the grounds that there was no qualification for a demand for trial. See Watanabe, Problems Connected with Tungsten Patent Light Bulbs, Section 5, pp. 1-5 and Conclusion, pp. 15-17.

30. Ibid., Section 3, p. 5 . Also see W. Itō, The Life of Seiichi Kishi, p. 97.

31. Watanabe, Problems Connected with Tungsten Patent Light Bulbs, Section 3, pp. 9-20. 
From the end of 1916 and on into 1919 submissions of written replies and written refutations, and the holding of oral examinations, followed one upon the other. The first result of the lawsuits appeared in August 1917, when Taishō Denkyū concluded an agreement with Tokyo Electric on the manufacture and sale of tungsten light bulbs, thereby placing itself under GE's umbrella. Taishō Denkyū later became Tokyo Electric's Kokura Factory, and it went on to become one of the major bases for light bulb manufacturing in the whole country. ${ }^{32}$ The lawsuits with Dainihon Denkyū and Kansai Denkyū carried on until 1919. In March 1919 the two of them were jointly involved in oral examinations and the like dealing with Patent No. 18961, and it looked as if they would fight the legal battles together until the end. ${ }^{33}$ But on the first of October Kansai Denkyū concluded a patent agreement with Tokyo Electric regarding the manufacture and sale of tungsten, and it came under the GE umbrella as well. This was soon followed by a similar agreement between Dainihon Denkyū and Tokyo Electric in December, by which Dainihon Denkyū also joined the GE group. ${ }^{34}$ In this manner, the lawsuits over tungsten light bulbs that had been filed one after another beginning in 1914, ended in 1919 in virtually a complete victory for GE. Through the trials GE not only was able to maintain the validity of the set of patents related to tungsten light bulbs that it was managing, it also managed to complete the concentration of Japan's light bulb industry in the hands of Tokyo Electric.

When we look at the tungsten patent trials and the process of concentrating the light bulb industry, it becomes readily apparent that the manager of the tungsten light bulb patents in Japan was GE, and that the form this management took was one of GE undertaking direct lawsuits, with Kishi acting as GE's patent attorney. The result of the trials was that the light bulb industry was reorganized with Tokyo Electric at the heart of it, and Tokyo Electric's power of control was strengthened, but the subject that possessed the strategies for concentrating operations in Tokyo Electric was GE, and it was GE that carried those strategies through to success and achieved the goals it had set out to achieve.

32. S. Yasui, A Fifty-Year History of Tokyo Electric Co., Ltd., p. 288.

33. Watanabe, Problems Connected with Tungsten Patent Light Bulbs, Sec. 7, pp. 299330.

34. Ibid., Conclusion, pp. 1-11. Also see Yasui, A Fifty-Year History, pp. 162-63. 


\section{Patent Management between the Wars via A "Proxy Application" Contract}

\section{The "Proxy Application" Contract with Tokyo Electric}

World War I brought about important changes both in the global economy and in international competitive relationships among electrical machinery companies, and Japan's electrical machinery industry also changed in that it made progress in the direction of greater domestic production during World War I. Confronted with this new global environment, GE put together a new strategy and organization to deal proactively with its overseas markets. In 1919 it set up a subsidiary, International General Electric Company (IGEC), specifically to handle the management of its international operations, and through this new organization it took on the global market in the years between the two world wars. In accordance with GE's new strategy, on 2 June 1919 IGEC negotiated a contract renewal with Tokyo Electric, concluding a new agreement with the latter. ${ }^{35}$ In the agreement between IGEC and Tokyo Electric some parts were considerably different from the earlier agreement in regard to patents, for now it included a contract covering "proxy application" by Tokyo Electric for GE patents.

The "proxy application" contract transferred to Tokyo Electric the right to apply in Japan for patented technology owned by GE; ${ }^{36}$ in its own name, Tokyo Electric could apply for and acquire a patent with itself as the rightful claimant in Japan. When Tokyo Electric merged with Shibaura Works, Ltd. in 1939 to form Tokyo-Shibaura Electric Co., Ltd., the agreement that IGEC concluded with Tokyo-Shibaura Electric was substantially the same as the 1919 agreement, and if we look at the contract provisions in the 1939 agreement we find in article 3 the following provision:

Section IV: The Tokyo-Shibaura Company may elect at its own expense to take out in its own name or to have assigned to it patents under which it is entitled to exclusive licenses hereunder and the General Company agrees that, in case the Tokyo-Shibaura Company

\section{S. Yasui, A Fifty-Year History, p. 288.}

36. The patented technology held by GE included, besides what it had itself developed, also the patented technology that had come into GE's possession through agreements with other companies. 
so elects, the General Company will use its best endeavors to cause the inventor or inventors in each case to do whatever is necessary or desirable so far as can be accomplished by enforcement of the contracts between the General Company and the inventors (but always at the expense of the Tokyo-Shibaura Company) to the end that the Tokyo-Shibaura Company may obtain and enforce such patents. This shall not require inventors to leave their home countries. ${ }^{37}$

A similar provision was contained in the 1919 agreement between IGEC and Tokyo Electric, and in accordance with this contract Tokyo Electric applied for, and registered, GE patents in its own name. ${ }^{38}$

Certain principles were laid down with regard to a "proxy application." 39 First of all, the patents Tokyo Electric could apply for were, as the words of the contract indicate, patents on technical areas under which Tokyo Electric was granted exclusive licenses. Secondly, as regards any patent for which "proxy application" was made, GE would transfer to Tokyo Electric the right to apply for a patent at a price of one dollar per application. ${ }^{40}$ Thirdly, Tokyo Electric would translate into Japanese any patent specification document sent from the United States and would submit it to the Japan Patent Office along with the attached deed of assignment. Fourthly, as also stated in the contract provision, Tokyo Electric would bear all expenses connected with patent management: the application fee, the annual fee, etc.

A huge amount of patent specifications were in fact sent from GE to Tokyo Electric on a regular basis. This does not mean that Tokyo Elec-

37. "Principal Agreement between International General Electric Company, Incorporated and Tokyo Shibaura Denki Kabushiki Kaisha, October 12, 1939," found in the Constitutional Government Reference Room of the Diet Library, GHQ/SCAP materials, CPC-04511, 04512.

38. Interviews held on 23 May 2001 with Mr. Haruo Seki, former managing director of Tokyo-Shibaura Electric, Mr. Köjirō Ozu, former head of the Patent Department of Tokyo-Shibaura Electric, and Mr. Hajime Takahashi, former chief engineer in the same department. Mr. Seki, who, when he joined the company, personally read the contracts exchanged by GE and IGEC with Tokyo Electric and Tokyo-Shibaura Electric, confirmed that a similar provision was in the 1919 agreement.

39. Interviews with Messrs Seki and Ozu.

40. The one dollar stipulation was made in order to emphasize the validity of the contract, "because the contract would not be considered legally valid unless there was a price," according to Mr. Seki. 
tric went ahead and submitted all the patent specifications that arrived. It had the right to choose which patents sent from GE to apply for, and it was also up to it to choose whether or not to keep paying the annual fee required for retaining a patent right. The decisions on which patents arriving from GE to apply for, and whether or not to continue paying the annual fee (i.e., whether or not to retain the patent right) were made by the Patent Section within Tokyo Electric. Only those patents deemed necessary for business purposes were applied for and registered in Japan. ${ }^{41}$

GE's adoption of the method of having Tokyo Electric manage patents acquired in Japan is believed to derive from certain advantages. The first advantage was that GE could use its patent rights and recover profits more efficiently. The patents that Tokyo Electric applied for at Japan's Patent Office according to the contract would only be patents that Tokyo Electric actually considered necessary for business purposes, and it would not apply for patents it judged to be unnecessary. Consequently, it would be able to build up a collection of patents suitable for competition in the Japanese market, and by using those patents to the fullest extent it could recover much more profit through shareholding dividends and the like.

The second advantage was that it was more profitable to have patent infringements and the like tackled by the company that was actually exercising the patent rights in that country and producing goods there. Tokyo Electric was actually manufacturing and selling the goods in Japan, and it was forced to raise business profits in the competitive environment of the Japanese economy. For this reason it would be sensitive to infringement of patent rights by a third party, and if a patent infringement should occur, Tokyo Electric would react to the infringement as something gravely impinging on its own good. (From the viewpoint of protecting one's patent right, also, management through a "proxy application" contract is effective.)

The third advantage was that all the necessary expenses were, according to the terms of the contract, borne by the Japanese side. Until this contract was concluded, GE had been making all the patent applications and managing the patents through the intermediacy of the patent attorney Seiichi Kishi. GE had been directly bearing the application fees and 
the annual fees. Huge costs could be involved if large numbers of patents were applied for and, when granted, retained by payment of annual fees, so IGEC was able, thanks to the contract, to manage the Japanese patents without bearing any of these costs. Since the actual owners of the patents applied for through the "proxy application" contract were, even in the contract itself, recognized to be GE and IGEC, ${ }^{42}$ this contract can accurately be termed an international patent management agreement by which IGEC could efficiently retain and administer patents in Japan during the years between the wars.

Making good use of the opportunity afforded by the contract renewal in 1919, GE changed the direct management mode it had followed till then in its international patent management in Japan to an indirect management mode by means of a "proxy application" contract, the same as it used in Great Britain and Germany. This change was based upon a recommendation in the report presented by the special GE committee that considered the establishment of IGEC; the report recommended that all contracts with overseas enterprises be revised so as to make them more suited to promoting aggressive overseas operations after the war. ${ }^{43}$ Once established, IGEC carried out the work of renewing contracts with all overseas enterprises through the 1920s; these contract renewals were carried out with a view to integrating the principal electrical machinery companies in the industrialized nations. ${ }^{44}$ It can be assumed that, on the occasion of the contract renewal with Tokyo Electric, too, GE's goal was to strengthen local production and allow Tokyo Electric to grow strong enough to become one of its "associated companies." International patent management by means of a "proxy application" contract is something that, because it involves passing the burden of patent management onto the patent implementing company, is done with independent local production in mind; the direct patent management mode followed by

42. In the previously mentioned agreement between IGEC and Tokyo-Shibaura Electric dated 12 October 1939, too, it is stated in article 3 section 7 that, when the contract expires, all patents return to IGEC; thus, it is safe to conclude that the ultimate proprietary rights over the patents resided in IGEC, not in Tokyo Electric. Mr. Seki also confirmed this in my interview with him.

43. General Electric, Executive file, Report upon Foreign Business, November 22, 1918, p. 5 (Schenectady Museum \& Archives).

44. Gerard Swope, Jr., "Historical Review of GE's Foreign Business As Affected by the U.S. Antitrust Laws," October 31, 1972, p. 18 (Schenectady Museum \& Archives). 
GE up to the outbreak of World War I, on the contrary, indicates that GE had at that time been thinking of Tokyo Electric as little more than a "branch factory."

\section{The Growth of Tokyo Electric's Organizational Capability}

In the specifications for the patents applied for as a result of the 1919 "proxy application" contract, the names given as the inventors were either GE or foreigners who belonged to associated companies of GE, while Tokyo Electric was given as the patentee. Figure 1 graphically represents the trends in the number of applications for inventions by foreigners. The figure shows how application to register inventions by foreigners began in 1919 and rapidly grew in numbers in the following years. Now, for GE to have Tokyo Electric act on its behalf in applying for and managing such a large number of Japanese patents, there had to be enough organizational capability within Tokyo Electric for it to be able to carry out patent management. So, as a final step in this study, let us look at how GE strengthened Tokyo Electric's organizational capability so that the former could advance its international patent management by means of the "proxy application" contract.

At that point in time when the "proxy application" contract was concluded, Tokyo Electric did not have any office that exclusively handled patent applications and patent management. Up to 1918, sixteen patents had been applied for in Tokyo Electric's name, but a portion of these patents were handled by a person in charge of applying for patents who had been given a desk in the laboratory in 1917. This person was Shigehachi Komatsu. ${ }^{45} \mathrm{Mr}$. Komatsu was an engineer for Tokyo Electric who was also involved in technical development; he gained patent attorney qualifications and was the first person so qualified at Tokyo Electric. This arrangement was inadequate for the job of handling GE patent applications. Even from an organizational standpoint, carrying out this work within a laboratory was not efficient, and there was a need for a special section to be set up to specialize in translating the specifications sent by GE, preparing the required paperwork, and looking after the patent rights-in short, to specialize in patent management.

45. Many of the patent specifications filed in this period did not contain the names of the patent attorneys, but Komatsu's name is given in the 16 May 1917 application for Patent No. 31368 and the 21 December 1917 application for Patent No. 33284. 
Figure 1. The Number of Tokyo Electric's "Proxy Application" Patent Cases

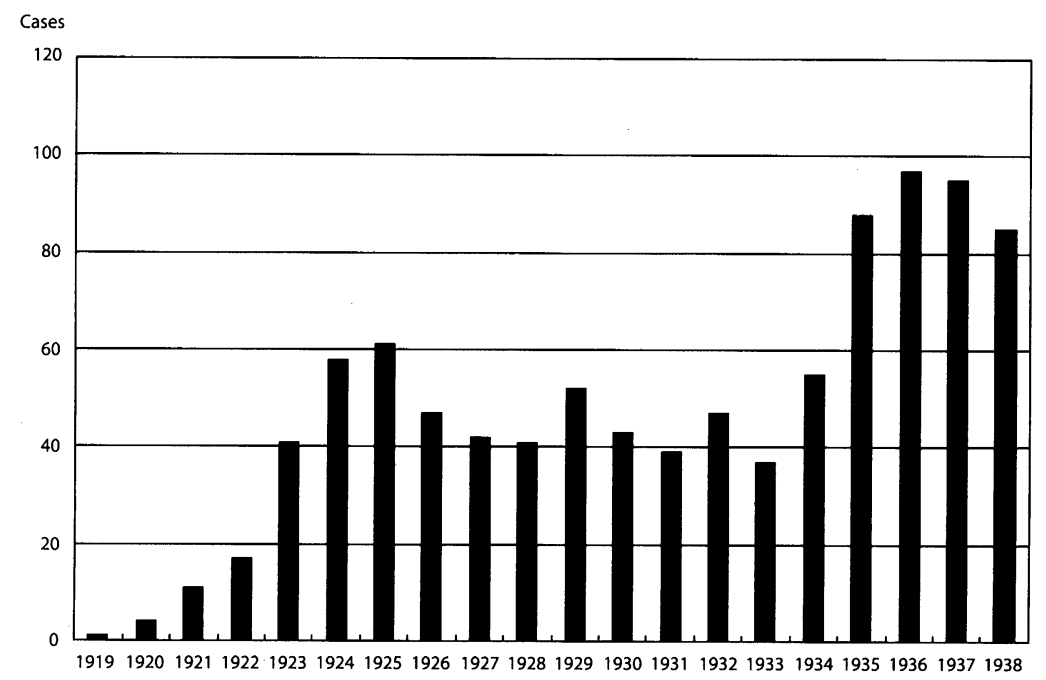

Source: The figures were compiled from the relevant issues of Patent Gazette.

It was J. R. Geary, the GE official who was responsible for the company's operations in Japan, who took the initiative on the establishment and strengthening of a patent section in Tokyo Electric. ${ }^{46}$ Even before the "proxy application" contract Geary was gradually allowing Tokyo Electric to take on some of the patent management functions. The first thing transferred to Tokyo electric had been the management of design - which, like a patent, carries with it an intellectual property right. On 25 March 1918 Tokyo Electric had submitted to the Patent Office a demand for trial for invalidation of design registration No. 13310, against Hisashirō Takaoka of Takaoka Denkyū Seisakusho. ${ }^{47}$ Tokyo Electric argued that the design of a frog-shaped ornamental light bulb owned by Takaoka was identical with an item that Tokyo Electric had been making since 1915 after obtaining the molds from GE, and so the design

46. Interview with Mr. Seki.

47. J. Watanabe, Problems Connected with Tungsten Patent Light Bulbs, Supplement 3 , pp. 1-3. 
registration was invalid. The demandant in this case was Tokyo Electric, and the patent attorneys were Komatsu and Iwao Shibayama (who was later to serve in Tokyo Electric's Patent Section). We can conclude that, although GE was carrying out direct management over patents, which were decisive in regulating the manufacture and sale of technological goods, so far as concerned light bulb design, which did not enjoy sufficient regulatory power to impact on the industry, GE was allowing its "branch factory" to take on some responsibility for management.

In order to have Tokyo Electric manage patents that dealt with creative embodiments of high-level technological ideas and to allow Tokyo Electric to grow into an "associated company" of GE as a result of the "proxy application" contract, Geary had a Patent Section directly responsible to the president of Tokyo Electric established in 1921. ${ }^{48}$ This new Patent Section was given a place in the organization that was independent of any research facility and manufacturing department; it was a specialized management section that was to concentrate on patent management for the company as a whole. When the Patent Section was established, its first head was Shigehachi Komatsu. By appointing as head of the Patent Section the person who had till then been in charge of its patent applications and who was well versed in matters to do with patents, Tokyo Electric set about putting together an efficient system for handling the job of filing GE patent applications.

A little more time was needed, however, for the transfer of patent management functions. If we look at the patent attorneys who handled the submission of GE patents by Tokyo Electric, we find that the name of Seiichi Kishi appears on applications made up to February 1922, so it is clear that at this time the arrangement was still one in which Kishi submitted GE patents in Tokyo Electric's name. ${ }^{49}$

In order to file applications for GE patents, it was necessary not only to possess specialized knowledge of patent application procedures and some legal knowledge, but also to translate English-language specifications into Japanese. Tokyo Electric had to flesh out the Patent Section

48. Interviews with Messrs Seki, Ozu, and Takahashi.

49. On those patents that give the name of the patent attorney-Patent No. 67655 filed on 6 May 1920, Patent No. 64301 filed on 2 August 1921, Patent No. 62360 filed on 14 December 1921, and Patent No. 44094 filed on 6 February 1922 (for all of which Tokyo Electric was the patentee) - in each case the attorney is Seiichi Kishi. 
that Komatsu was put in charge of with personnel and the requisite capabilities, and it took time to make the necessary preparations. From March 1922 the name of the patent attorney appearing on patent specifications was that of Shigehachi Komatsu, so it seems we can assume that this point in time marked the beginning of GE patent application administration by the Patent Section. With the beginning of applications for GE patents under the headship of Komatsu three years after the "proxy application" contract and one year after the Patent Section was established, we have the completion of the arrangement whereby GE would manage the Japanese patents through the patent management functions of Tokyo Electric.

International patent management based on the "proxy application" contract seemed headed for smooth sailing. But then the Great Kantō Earthquake struck on 1 September 1923; Tokyo Electric buildings were demolished, and Komatsu was among the victims of the earthquake..$^{50}$ Komatsu's replacement was Shibayama. ${ }^{51}$ As we saw earlier, Shibayama served together with Komatsu as Tokyo Electric's patent attorney in the design patent case, but at that time he was not a Tokyo Electric employee. ${ }^{52}$ Almost two months after the Great Kantō Earthquake, on 29 October 1923, he became an employee of Tokyo Electric and moved his office into Tokyo Electric premises. Replacing Komatsu, he served as the head of the Patent Section for approximately one year.

The Great Kantō Earthquake notwithstanding, the number of applications for GE patents steadily increased, while at the same time the number of patent applications that the Patent Section filed for proposals put forward from within the company, especially from research facilities, also went on increasing. To handle the growing work, the capabilities of the Patent Section had to be extended and improved greatly. And so in 1923 Tokyo Electric prevailed upon Rinji Fujii, a Patent Office technician, to join the company, and in 1924 appointed him head of the Patent

50. S. Yasui, A Fifty-Year History, pp. 180-81.

51. Interviews with Messrs Ozu and Takahashi.

52. The address of Shibayama's office as given on the bill of complaint was "Tōkyōshi Azabu-ku Sakurada-chō 17 banchi", while that of Komatsu's office was given as "Kanagawa-ken Tachibana-gun Kawasaki-chō Horinouchi 752 banchi, Tōkyō Denki Kabushikigaisha-nai." Given his address, Shibayama is believed not to have been a Tokyo Electric employee. See J. Watanabe, Problems Connected with Tungsten Patent Light Bulbs, Supplement 3, pp. 1-3. 
Section. ${ }^{53}$ While employed as a Patent Office technician, Fujii had been involved until a short time before he left the Patent Office in the series of electric light bulb patent trials instituted by GE. ${ }^{54}$ With the naming of Fujii, with his detailed knowledge of patent administration and his involvement in GE's patent trials, to be the head of the Patent Section, the interwar international patent management system based on the "proxy application" contract had become, functionally as well, complete.

\section{Conclusion}

A concluding statement along the lines of the two tasks I set myself at the beginning of this paper would, I suppose, take the following form.

The first task was that of comparing the method of international patent management between the wars with the way international patents were managed before World War I, and doing this in the light of international comparisons. Before World War I GE managed its Japanese patents itself, directly; GE itself pursued the tungsten patent trials and made sure the light bulb industry was concentrated in Tokyo Electric. After the war, however, the patent agreement that IGEC concluded with Tokyo Electric included a contract whereby Tokyo Electric submitted in its own name GE patents to the Japanese patent office and managed them. This "proxy application" contract allowed Tokyo Electric to manage GE's Japanese patents. GE had earlier concluded similar contracts with British Thomson-Houston Co. and AEG of Germany, but in 1919 it concluded this kind of contract with Tokyo Electric and did what it could to make the latter grow into one of the "associated companies" that GE had scattered around the globe.

The second task was that of providing a clear picture of the transfer of patent management functions from GE to Tokyo Electric in the early 1920s. In order for GE to bring about Tokyo Electric's growth into an

53. Interviews with Messrs Ozu and Takahashi. Also see Jinji Kōshinjo [Personnel inquiry agency], Jinji Kōshin-roku [Records of personnel inquiries], 13th ed. (Tokyo: Jinji Kōshinjo, 1931).

54. Thus, for example, Fujii, as the Patent Office technician, took part in the 22 April 1920 trial decision in connection with Trial No. 3442 (a demand for trial for invalidation of the Coolidge patents case). See Japan Patent Office, comp., Tokkyo kōhō [Patent Gazette] no. 362 (28 May 1920). 
"associated company" and hand over to it the work of applying for GE patents in Japan, GE had to set up Tokyo Electric's patent management organization. GE's representative, Geary, established in 1921 a Patent Section that was directly responsible to the president of the company; with respect to the personnel side, too, Geary strengthened the Patent Section by recruiting Rinji Fujii, a Patent Office technician who had been involved in the tungsten patent trials. Fujii led the Patent Section through to Tokyo Electric's 1939 merger with Shibaura Works, fulfilling a major role in GE's international patent management. By its method of international patent management through use of the patent management functions of an "associated company," GE had carried forward its corporate internationalization. 